\title{
REVIEW
}

\section{BACTERIOLOGICAL HAZARDS AND RISKS ASSOCIATED WITH SEAFOOD CONSUMPTION IN BRAZIL}

Carlos A.M. Lima dos SANTOS(1) \& Regine H. S. Fernandes VIEIRA(2)

\begin{abstract}
SUMMARY
The present study is a review of data available in Brazil on bacterial diseases transmitted through the consumption of seafood and related products. Data are presented regarding outbreaks and cases of disease and laboratory findings associated with pathogens in seafood and related products, and methods for prevention and control are described.
\end{abstract}

KEYWORDS: Seafood safety; Bacterial hazards; Human health.

\section{INTRODUCTION}

Food-borne illnesses are among the most frequent public health problems in the contemporary world. However, in most countries reliable statistical information can be hard to obtain, in part because most cases of food-borne illnesses are never reported. Due to the mildness of the symptoms, many victims simply do not seek medical care.

Recent data from the National Department of Health Surveillance (SVS, Brazil) $)^{104}$ show the occurrence of 6,602 outbreaks of food-borne illnesses in Brazil between 1999 and 2008, of which only 69 were associated with seafood consumption. According to the SVS, these figures are far from the actual number of outbreaks $(<5 \%)$. Most of the registered outbreaks $(84 \%)$ were caused by pathogenic bacteria and/ or bacterial toxins, with predominance of Salmonella, Staphylococcus, Bacillus cereus, Clostridium perfringens, Shigella and other bacteria $(>1 \%)$ followed by virus $(13.6 \%)$, chemical contaminants $(1.2 \%)$ and parasites $(1 \%)$.

According to the System of Regional Information on Epidemiological Surveillance of Foodborne Illnesses (SIRVETA, Brazil), 6,930 outbreaks of food-borne illnesses were registered in the Americas between 1993 and $2002,17.8 \%$ of which were caused by contaminated seafood ${ }^{28,85}$.

Although the periods covered by the FAO data (1993-2002) and the SVS data (1999-2008) do not allow for a direct comparison, the figures suggest that the incidence of seafood-borne illnesses is significantly lower in Brazil (> 5\%) than in the Americas as a whole (17.8\%).

The objective of this study was to identify the bacteriological hazards and risks associated with the consumption of seafood and related products in Brazil and discuss prevention and control strategies. Most of the information reproduced in this article was retrieved from scientific databases, including Bireme, Scielo, Science Direct and PubMed.

Pathogenic bacteria and seafood: Like other types of food, seafood has a unique microbiota which may be affected by factors external to the animal's habitat, whether it be estuarine, lacustrine or marine. Examples include contamination from discharged sewage and polluted waterways $^{108}$.

Seafood-borne illnesses may be caused by biological, chemical or physical agents. Biological pathogens are represented by a vast array of bacteria, viruses and parasites. According to HUSS et al.$^{47}$, pathogenic bacteria found in seafood and related products may be divided into three groups: 1) bacteria that may be naturally present in the habitat of the consumed species, such as Vibrio spp. (V.parahaemolyticus, V. cholerae, V. vulnificus), non-proteolytic Clostridium botulinum type B, E and T, Plesiomonas shigelloides and Aeromonas spp; 2) bacteria present in the environment in general (Listeria monocytogenes, proteolytic Clostridium botulinum type A and B, Clostridium perfringens and Bacillus spp; 3) bacteria which have their usual habitat in man or animals (Salmonella spp., Shigella spp., Escherichia coli, Campylobacter jejuni and Staphylococcus aureus).

The presence of Huss Group 1 and 2 bacteria in live fish or fresh raw fish is rarely a safety concern because tissue concentrations are too low to cause disease. However, the accumulation of large numbers of pathogens (Vibrio spp.) in filter-feeding shellfish represents a risk, especially since shellfish are often consumed raw. Pre-harvesting contamination with pathogens from the animal-human reservoir (Huss Group 3) may pose a risk since in some cases a very low infective dose is enough to cause

(1) International Consultant, Academy of Veterinary Medicine of the State of Rio de Janeiro, Rio de Janeiro, RJ, Brazil. E-mail: dossantoscarlos@ globo.com

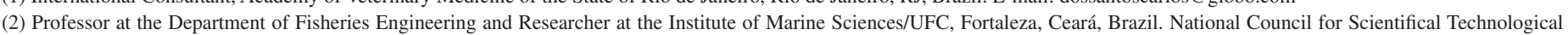
Development (CNPq) Researcher.

Correspondence to: Regine H.S. Fernandes Vieira. E-mail: reginevieira@terra.com.br 
illness (1+/- 10 Shigella and Salmonella serotypes). Normal cooking procedures will eliminate the risk of contamination. Safety concerns are therefore primarily related to the consumption of raw shellfish and raw fish dishes like ceviche or sushi ${ }^{47}$.

The above principles also apply to aquacultured fish, inclusive to fish cultivated in integrated systems (fish-cum-pig, fish-cum-duck, etc.) and waste water

To control these bacteria, preventing them from contaminating seafood and causing illness, extensive knowledge is required regarding their origin, biology, physiology, ecology, survival, growth and prevalence in seafood and related products, along with the epidemiology and symptomatology of the diseases with which they are associated.

Clostridium botulinum: Clostridium botulinum is a strictly anaerobic, Gram-positive, peritrichous, rod-shaped, spore and gasforming bacterium ubiquitous in soils and aquatic sediments. The organism is classified into types according to serological specificity. Each type secretes a different toxin, referred to as A, B, C, D, E, F and G. When found in humans, the E type is usually associated with the consumption of seafood and related products ${ }^{31,99}$. According to KETCHAM \& GOMEZ ${ }^{52}$, spores of the $\mathrm{E}$ type can germinate at temperatures below $3^{\circ} \mathrm{C}$ and are often found in association with cold-stored seafood.

Botulinum toxin is an active exotoxin (even more so than tetanus toxin) with neurotropic action (affecting the nervous system). It is the only bacterial toxin which can be fatal upon ingestion and may be regarded as a biological poison. It is lethal at very small doses (1/100-1/120 ng). Unlike the spores, the toxin is thermolabile and is destroyed if exposed to $65-80{ }^{\circ} \mathrm{C}$ for 30 minutes, or to $100{ }^{\circ} \mathrm{C}$ for five minutes ${ }^{25}$, whereas according to KETCHAM \& GOMEZ ${ }^{52}$, spores in contaminated food may be destroyed if exposed to $120^{\circ} \mathrm{C}$ for 30 minutes. In packaged and sealed foodstuffs, spores germinate under anaerobic conditions provided the $\mathrm{pH}$ value is above 4.5 and there is enough water activity. Thus, once the spores in packaged foods have germinated, vegetative cells will produce botulinum toxin during storage ${ }^{95}$.

Non-proteolytic Clostridium botulinum type B, E and F primarily inhabit temperate and arctic aquatic environments, whereas type $\mathrm{E}$ multiplies in putrefying aquatic organisms, usually at low densities $(<0.1 \text { spores/g fish, though exceptionally up to } 5.3 \text { spores/g fish })^{47}$.

Vibrio spp: The genus Vibrio consists of Gram-negative, curved rod-shaped facultative anaerobes endowed with a single polar flagellum. The genus includes at least 12 species pathogenic to man, 10 of which may be foodborne. Most Vibrio-related food-borne illnesses are caused by $V$. parahaemolyticus, $V$. cholerae and $V$. vulnificus ${ }^{20,71,72,75,108}$. $V$. parahaemolyticus and $V$. cholerae have been isolated in cases of gastroenteritis caused by contaminated food (both species) and contaminated water (the latter). V. vulnificus is mainly observed in extraintestinal infections (septicemia, wounds etc.). Primary septicemia caused by $V$. vulnificus is usually associated with the consumption of seafood, especially raw bivalves.

Pathogenic vibrios, especially $V$. cholerae, also occur in fresh water and in estuaries ${ }^{21}$ to which it may be introduced by way of fecal contamination. Unlike most other vibrios, $V$. cholerae can survive in fresh water. The mechanisms of epidemic pathogenicity of $V$. cholerae and $V$. parahaemolyticus have been extensively investigated and are well known. Environmental strains of these bacteria may be virulent or not, depending on their ability to produce virulence factors. An important pathogen, $V$. vulnificus is associated with high levels of fatality, but fortunately infections are rare and tend to be limited to individuals with chronic disease or immunodeficiency ${ }^{117}$.

Characteristics shared by most Vibrio species include sensitivity to low $\mathrm{pH}$ values, infrequent association with highly acidic foods, and inhibition of virulence by adequate cooking. However, the three most pathogenic vibrio species differ in a number of important aspects.

Vibrio parahaemolyticus: This mobile, Gram-negative and rodshaped microorganism is distributed worldwide in marine environments, but is most abundant in warmer regions. It is often isolated from seafood of marine and estuarine origin, especially bivalves ${ }^{102}$. It is found on aquatic animals, especially crustaceans and mollusks, at temperatures above $8{ }^{\circ} \mathrm{C}$ and thrives in alkaline media containing $2-4 \% \mathrm{NaCl}$ at $37^{\circ} \mathrm{C}$. Due to its high turnover rate (5-10 $\mathrm{min})$ under appropriate conditions and its ability to compete with other microorganisms, a small number of infecting cells in seafood at room temperature rapidly becomes a threat to seafood consumers.

V. parahaemolyticus can cause diarrhea, cramping abdominal pain, vomiting, fever and headaches at a concentration of $10^{6}-10^{9} \mathrm{CFU} / \mathrm{g}$. As a mesophilous organism, $V$. parahaemolyticus is easily eliminated from seafood by exposure to heat, but when seafood is served raw (such as oysters, mussels, sushi, sashimi and carpaccio), consumers are at risk of infection ${ }^{46}$. According to Brazilian regulations (RDC 12), the maximum concentration of $V$. parahaemolyticus allowed in foodstuffs is $10^{3} \mathrm{CFU} / \mathrm{g}^{9}$.

In 1965, an analysis of strains of $V$. parahaemolyticus from gastroenteritis patients at a hospital in Yokohama, Japan, revealed a hemolytic enzyme - thermostable direct hemolysin (TDH) - not observed in isolates from seafood and the environment. The presence of TDH, as detected by the Kanagawa test, is associated with enteropathogenicity ${ }^{119}$. Strains of V. parahaemolyticus can cause serious infectious outbreaks if they carry the genes $t d h$ and/or $t r h^{73}$ or if they are capable of hydrolyzing urea and inducing beta-hemolysis in blood agar $^{49,74}$.

The risks associated with the consumption of seafood contaminated with $V$. parahaemolyticus were evaluated in a recent study published jointly by the World Health Organization and the Food and Agriculture Organization of the United Nations ${ }^{118}$.

Vibrio cholerae: V. cholerae occurs naturally in fresh and brackish water in tropical, subtropical and temperate regions. Strains of serotype $\mathrm{O} 1$ and $\mathrm{O} 139$ usually carry the gene $\operatorname{ctx}$ and produce cholera toxin. These toxigenic strains are responsible for cholera epidemics around the world. The disease is exclusively human and human feces are the primary source of infection. Cholera epidemics are mostly restricted to developing countries at warmer latitudes ${ }^{115}$. The contamination of environments involved in food production (including aquaculture ponds) with feces from infected individuals may indirectly introduce toxigenic $V$. cholerae strains into foodstuffs. The concentration of free toxigenic $V$. cholerae in the natural environment is low, although the species is known to be capable of attaching to and multiplying on zooplankton (copepods) ${ }^{44}$. 
Strains of V. cholerae $\mathrm{O} 1$ may be classified into two biotypes, Classic and El Tor, based on phenotypic traits ${ }^{51}$. For unclear reasons, infection tends to be more severe when caused by the Classic biotype than by El Tor. Approximately $20 \%$ of infected individuals develop acute aqueous diarrhea, which in 10-20\% of cases evolve into severe aqueous diarrhea with vomiting. Without immediate and proper treatment, the infection can lead to intense dehydration and death in a matter of hours, with a fatality rate up to $30-50 \%$ among family members. However, when treatment is timely and adequate, fatality rates are reduced to less than $1 \% \mathrm{O}$ serotypes other than $\mathrm{O} 1 \mathrm{e} \mathrm{O} 139$, referred to as non-O1/O139 strains, can induce food-related diarrhea which is less severe than illness associated with cholera ${ }^{116}$.

Vibrio vulnificus: Phenotypically, V. vulnificus is highly homologous with $V$. parahaemolyticus, but differs by its ability to ferment lactose, justifying its early classification as "lactose-positive vibrio". According to ELLIOT et al. ${ }^{27}$, strains of $V$. parahaemolyticus and $V$. vulnificus may be differentiated by several biochemical tests, such as the $\beta$-galactosidase assay. The name V. vulnificus was formally adopted in $1979^{43}$.

Clinical and epidemiological investigations have shown that $V$. vulnificus can cause septicemia and death in humans through contaminated seafood (by penetrating the blood stream from the gastrointestinal tract) or through wounds exposed to contaminated marine environments ${ }^{4}$.

According to HUSS et al. ${ }^{47}$, V. vulnificus produces extracellular cytotoxins and hydrolytic enzymes capable of rapid muscle tissue degradation during infection. The presence of capsular polysaccharide is essential to trigger the infectious process. Three biotypes of $V$. vulnificus have been identified: approximately $85 \%$ of strains isolated from clinical samples belong to biotype 1 , while biotype 2 is known to cause infection in eels. Biotype 3 was first described recently in association with seafoodrelated bacteremia.

Salmonella spp: Infection by Salmonella (salmonellosis) is the main cause of food-borne illnesses worldwide and a major socioeconomic problem $^{6}$. The incubation period is 5-72 hours (usually 12-36 hours) following contamination and infection lasts 4-7 days. The symptoms include nausea, vomiting, cramping abdominal pain, fever, headache and diarrhea ${ }^{15,84}$. Seafood may be contaminated in the fishing or farming environment ${ }^{37}$ or during harvesting, processing and marketing ${ }^{53}$.

The incidence and role of Salmonella in seafood safety was recently reviewed by AMAGLIANI et $a l{ }^{8}$. In their review AMAGLIANI et $a l .{ }^{8}$ presented comprehensive updated epidemiological data about salmonellosis outbreaks and Salmonella occurrence in seafood in selected industrialized and developing countries. Quoting CDC those authors indicated that a total of 838 foodborne illness outbreaks with 7298 illnesses linked to seafood occurred in the USA between 1998 and 2001.

Escherichia coli: Among the coliform bacteria thriving at up to $45^{\circ} \mathrm{C}$ for which maximum concentrations have been specified in Brazilian regulations (RDC 12) $)^{9}$, Escherichia coli is the species most often associated with infection. According to TRABULSI \& ALTERTHUM $^{106}$, the pathogenic diversity of $E$. coli is impressive. There are at least five categories which cause intestinal infection by different mechanisms in addition to categories associated with urinary infections, meningitis and other extraintestinal infections. Categories inducing intestinal infection are collectively termed diarrheagenic $E$. coli, while those associated with extraintestinal infections are referred to as ExPEC.

Staphyloccocus spp: The genus Staphylococcus belongs to the family Micrococcaceae and includes 74 species $^{24}$. The cells are round, Gram-positive and form grape-like clusters. They are immobile, non-spore-forming and most species are facultative anaerobes. Staphylococci may be differentiated with the coagulase test: coagulasepositive species include $S$. aureus, $S$. intermedius, $S$. delphini and some strains of $S$. hyicus and $S$. schleiferi. With the exception of $S$. aureus, these species are isolated from animals but very rarely from humans. Thus, in almost all clinical laboratories, coagulase-positive staphylococci isolated from human sources or manipulated by humans are assumed to be $S$. aureus ${ }^{55}$.

Staphylococcus is not a natural component of seafood microbiota. According to HUSS ${ }^{46}$, seafood becomes contaminated with Staphylococcus by exposure to infected handlers and environments. The origin of the contamination is often an individual with infected hands, constipation or sore throat. The presence of staphylococci in naturally contaminated raw foods offers little risk, but if precooked seafood (such as shrimp) is recontaminated with $S$. aureus under favorable time and temperature conditions, even a very small number of $S$. aureus will proliferate rapidly and produce harmful enterotoxins. These toxins are generally very resistant to proteolytic enzymes and heat. Thus, while proper cooking can prevent staphylococcal proliferation and toxin formation, once formed the toxin resists boiling $\left(100^{\circ} \mathrm{C}\right)$ for 30 minutes. There are no reports of Staphylococcus outbreaks caused by industrialized canned food, but in the home setting the heat used to pasteurize and cook seafood is insufficient to destroy the toxin ${ }^{47}$.

Listeria monocytogenes: Listeria monocytogenes is Gram-positive and moves with the aid of a flagellum. The genus has many members, but $L$. monocytogenes is the species most frequently associated with food-borne illnesses. It is ubiquitous and occurs naturally in soil, mammals, birds, fish, crustaceans and mollusks. L. monocytogenes can resist freezing, drying and heat. Listeriosis, the disease caused by this microorganism, may take the form of septicemia, meningitis, encephalitis or intrauterine and cervical infections in pregnant women, leading to spontaneous abortion in the $2^{\text {nd }}$ or $3^{\text {rd }}$ quarter, or preterm birth. Infection with L. monocytogenes has been associated with the consumption of unpasteurized milk, soft cheese, ice-cream, raw vegetables, sausage made of raw fermented meat, raw or cooked poultry, raw meat of any type, and raw/smoked seafood. The ability to grow at temperatures as low as $-3{ }^{\circ} \mathrm{C}$ makes it possible for $L$. monocytogenes to multiply in cold-stored foods ${ }^{23,29}$.

Outbreaks of seafood-borne bacterial illnesses in Brazil: Recently published reviews by SANTOS ${ }^{93,94}$ indicate a relatively small number of outbreaks of seafood-borne illnesses associated with pathogenic bacteria in Brazil in the period 1983-2010. This is supported by our own review. Table 1 presents updated information on etiological agents, outbreaks and deaths caused by seafood-borne illnesses associated with pathogenic bacteria in Brazil during the period 1983-2010.

Botulism: According to SANTIAGO ${ }^{92}$, the first botulism epidemic in Brazil was registered in 1958, in the state of Rio Grande do Sul, when nine individuals died as a result of consuming home-canned fish. 
Table 1

Etiological agents, outbreaks, cases and deaths caused by seafood-related bacterial foodborne illnesses in Brazil in the period 1983-2010

\begin{tabular}{lcccc}
\hline Etiology & Outbreaks & Cases & Deaths & References \\
\hline V. parahaemolyticus & 2 & 31 & 0 & $38,62,32$ \\
C. botulinum & - & 1 & 0 & 19 \\
Salmonella Newport & - & 1 & 0 & 40 \\
Salmonella spp. & - & 1 & 0 & 12 \\
\hline TOTAL & 2 & 34 & 0 &
\end{tabular}

EDUARDO \& SIKUSAWA ${ }^{26}$ outlined the epidemiological profile of a historical series of reports of botulism diagnosed in Brazil from 1979 to 2002, covering 125 cases and 75 deaths. Only 31 (24.8\%) of the 125 cases were reported, $79 \%$ of which occurred in 2001/2002, with a lethality of $60 \%$. Botulinum toxin type A was identified in eleven episodes (69\%). The first Brazilian case reported to the SVS occurred in 1999, and from then on to 2004 another 41 suspected cases were reported, of which 19 were confirmed: one case of wound botulism and 18 cases of foodborne botulism. Among the latter, $77.8 \%$ were caused by pork products, $11.1 \%$ by canned heart of palm and $11.1 \%$ by food of unidentified origin. Despite being considered an emergency situation in public health, botulinum intoxication first became regulated and monitored in 1999, in the state of São Paulo. Later, in October 2001, the Brazilian Ministry of Health made reporting compulsory nationwide.

As shown by GELLI et $a l .{ }^{34}$, laboratory studies from the period 1982-2001 confirm the occurrence of outbreaks/cases of botulism in Brazil. Botulinum toxin type A was identified in seven episodes, but no cases were associated with seafood consumption.

In 2007, an isolated case of botulism caused by home-canned fish was confirmed and reported to the Center of Epidemiological Surveillance of São Paulo (CVE-SP) in Sorocaba. The victim was cured and survived ${ }^{19}$.

Vibriosis: Vibrio cholerae non-O1 was found to be associated with human infection in an outbreak of gastroenteritis in the state of Bahia in $1974^{39}$. The species was identified in samples from five individuals and in drinking water, suggesting it was originally waterborne.

V. parahaemolyticus (serotype O5:K17, confirmed Kanagawapositive by a specialized laboratory in Japan) was first isolated from humans in Brazil in $1983^{38}$. The sample came from the aqueous diarrhea of a 6 year-old child from Cascavel, State of Ceará. No epidemiological information is available, except for the fact that the local population is known to consume considerable amounts of salt-cured marine and freshwater fish.

MAGALHÃES et al. ${ }^{60,62}$ analyzed 1,100 diarrheal fecal samples from Recife, Pernambuco State, 14 (1.3\%) of which were contaminated with V. parahaemolyticus. The contaminated individuals presented symptoms of gastroenteritis (cramping abdominal pain, nausea, vomiting, fever, chills and headache). The infection was attributed to oysters $(n=5)$, shrimp $(n=4)$, fish $(n=3)$ and octopus $(n=2)$. The microbiological studies revealed seven $\mathrm{K}$-antigen serotypes and three unidentifiable serotypes among the isolates.
An outbreak of gastroenteritis registered in Fortaleza, Ceará State, involved 26 individuals from whom 20 rectal swab samples were collected for analysis. V. parahaemolyticus was detected in nine samples (45\%), six of which were shipped to the Oswaldo Cruz Foundation (Rio de Janeiro) for diagnostic confirmation and found to be V. parahaemolyticus O3:K6 (Kanagawa-positive). According to the epidemiological study, the source of the infection was most likely raw crab claws served at the restaurant of a local hotel ${ }^{32}$.

V. fluvialis and V. fumissii were reported by MAGALHÃES et al. to have caused an outbreak of foodborne diarrhea in infants, but no food source was mentioned ${ }^{61}$. The incident is mentioned in the present review due to the common finding of these vibrio species in seafood.

Salmonellosis: In Brazil, the reporting of salmonellosis is compulsory. However, according to HOFER \& REIS ${ }^{40}$, an economic analysis of the losses associated with Salmonella outbreaks is difficult due to the scarcity of Brazilian literature on the subject.

HOFER \& REIS ${ }^{40}$ reviewed 25 outbreaks of Salmonella in Brazil registered in the period 1982-1991, one of which (from Curitiba, Paraná) was associated with consumption of cooked fish. The serotype was identified as $S$. Newport.

A seafood-related case of salmonellosis registered in Limeira (São Paulo) in 2005/2006 was recently described by BARRETO \& STURION $^{12}$. According to the methodology employed by the CVE-SP, the food/preparation responsible for this sporadic case was most likely seafood of unspecified type. The method is based on the calculation of the relative risk (RR) of each food/preparation.

Staphylococcal intoxication: Although Staphylococcus aureus is not a marine microorganism, it may be found in seafood due to contact with contaminated food and implements, especially if exposed to extended storage at temperatures favorable to proliferation ${ }^{108}$.

Official statistics indicate Staphylococcus aureus as a major cause of food toxi-infection in Brazil. However, no cases have been reported in this country involving seafood or related products.

Incidence of pathogenic bacteria in seafood in Brazil: Covering the period 1983-2011, the literature reviewed for this study contains numerous reports of bacteria pathogenic to humans isolated from seafood and related products throughout Brazil. Unofficial data published in scientific journals provide a more accurate picture of the occurrence of pathogenic bacteria in seafood in the country, along with information on epidemiological trends, indicating areas requiring special attention from public health authorities.

Tables 2 to 7 show available published data on the presence of Vibrio parahaemolyticus (Table 2), other Vibrio spp. (Table 3), Salmonella spp. (Table 4), Escherichia coli and coliforms (Table 5), Staphylococcus spp. (Table 6) and Listeria spp. (Table 7) in seafood in Brazil.

Prevention and control: The pathogenic bacteria most commonly associated with seafood-borne illnesses originate from the environment (Huss Group I). Therefore, measures of prevention and control have to be in place from the time of capture/culture. In other words, seafood 
Table 2

Isolation of Vibrio parahaemolyticus from seafood in Brazil (product, location, reference)

\begin{tabular}{lcc}
\hline Product & Location & Reference \\
\hline Bivalves & Recife, PE & 58 \\
Shrimp (Litopenaeus vannamei) & Natal, RN & 65 \\
Mangrove crab (Ucides cordatus) & Fortaleza, CE & 113 \\
Brown mussel (Perna perna) & Palhoça, SC & 10 \\
& Niteroi, RJ & $79,80,83$ \\
& Rio de Janeiro, RJ & 54 \\
Spiny lobster (Panulirus & Fortaleza, CE & 112 \\
laevicauda) & & \\
Oyster (Crassostrea brasiliana) & Sepetiba, RJ & 42,88 \\
& Cananéia, SP & 87 \\
Oyster (C. gigas) & São Paulo, SP & 35,63 \\
Oyster (C. rizophorae) & Recife, PE & 60 \\
& Euzébio, CE & 100 \\
& Fortaleza, CE & 111,114 \\
Oyster and mussel & Rio de Janeiro, RJ & 80,81 \\
Carib pointed venus & São Paulo, SP & 17,91 \\
(Anomalocardia brasiliana) & São Luis, MA & 96 \\
Swamp mussel (Mytella falcata) & & \\
Fish, crustaceans, bivalves & São Paulo, SP & 56 \\
\hline
\end{tabular}

$\mathrm{CE}=$ Ceará; $\mathrm{SC}=$ Santa Catarina $; \mathrm{PE}=$ Pernambuco $; \mathrm{RJ}=$ Rio de Janeiro $; \mathrm{RN}=$ Rio Grande do Norte; SP = São Paulo; MA = Maranhão.

Table 3

Isolation of Vibrio species other than V. parahaemolyticus from seafood in Brazil (product, location, reference)

\begin{tabular}{lcc}
\hline Product & Location & Reference \\
\hline Shrimp (Litopenaeues vannamei) & Sobral, CE & 16 \\
Shrimp (Penaeus subtilis, P. & Fortaleza, CE & 110 \\
Schmittii, P. brasilienses) & & \\
Shrimp (Xiphopenaeus kroyeri) & Fortaleza, CE & 69 \\
Mangrove crab (Ucides cordata) & Fortaleza, CE & 113 \\
Spiny lobster (Panulirus & Fortaleza, CE & 112 \\
laevicauda) & & \\
Brown mussel (Perna perna) & Niterói, RJ & 79 \\
& Rio de Janeiro, RJ & 54 \\
Oyster (Crassostrea brasiliana) & Sepetiba, RJ & 88 \\
& Cananéia, SP & 87 \\
Oyster (C. gigas) & São Paulo, SP & 63 \\
Oyster (C. rhizophorae) & Fortaleza, CE & 100 \\
& Euzébio, CE & 114 \\
& Itapissuna, PE & 67 \\
& Rio de Janeiro, RJ & 78 \\
Fish from marketplace & São Paulo, SP & 64,97
\end{tabular}

$\mathrm{CE}=$ Ceará; PE = Pernambuco; RJ = Rio de Janeiro; SP = São Paulo.
Table 4

Isolation of Salmonella from seafood in Brazil (product, location, reference)

\begin{tabular}{lcc}
\hline Product & Location & Reference \\
\hline Tunafish and weakfish & São Paulo, SP & 5 \\
Cod (Gadus morrhua ) & Niterói, RJ & 3 \\
Shrimp (Litopenaeus vannamei) & Jaguaribe, CE & 14 \\
Mangrove crab (Ucides cordatus) & Fortaleza, CE & 113 \\
Frog meat (Leptodactylus sp. ) & Niterói, RJ & 90 \\
White croaker (Micropogon furnieri) & Porto Alegre, RS & 89 \\
Farmed freshwater fish & São Paulo, SP & 57 \\
Fresh and frozen fish & Botucatu, SP & 86 \\
Spotted sorubim (Pseudoplatystoma & Pantanal, MG & 2 \\
corruscans) & & \\
Tilapia (Oreochromis sp.) & Divinópolis, MG & 68 \\
& Campina Grande, PB & 107 \\
& Alfenas, MG & 76 \\
\hline CE = Ceará; MG = Minas Gerais; RJ = Rio de Janeiro; RS = Rio Grande do Sul; \\
SP = São Paulo; PB = Paraíba. &
\end{tabular}

Table 5

Isolation of Escherichia coli and other coliforms from seafood in Brazil (product, location, reference)

\begin{tabular}{lcc}
\hline Product & Location & Reference \\
\hline Bivalves & Florianópolis, SC & 11 \\
Shrimp (Litopenaus vannameii) & Shrimp farms, CE & 77 \\
Shrimp (Penaeus paulensis) & Florianópolis, SC & 11 \\
Shrimp (Xyphopenaeus kroyeri) & Fortaleza, CE & 105 \\
Oyster (Crassostrea gigas) & Florianópolis, SC & 82 \\
Oyster (C. rhizophorae) & Rio Cocó, CE & 97 \\
& Rio Pacoti, CE & 109 \\
Red snapper (Lutjanus purpureus) & Fortaleza, CE & 105 \\
Fish from marketplace & São Paulo, SP & 98 \\
Blue crab (Calinectes sapidus) & Florianópolis, SC & 11 \\
\hline
\end{tabular}

$\mathrm{CE}=$ Ceará; $\mathrm{SC}=$ Santa Catarina; $\mathrm{PR}=$ Paraná; $\mathrm{SP}=$ São Paulo.

Table 6

Isolation of Staphylococcus aureus from seafood in Brazil (product, location, reference)

\begin{tabular}{lcc}
\hline Product & Location & Reference \\
\hline $\begin{array}{l}\text { Red-clawed mangrove } \\
\text { tree crab (Goniopsis cruentata) }\end{array}$ & Recife, PE & 66 \\
Bivalves & Florianópolis, SC & 11 \\
Shrimp (Penaeus paulensis) & Florianópolis, SC & 11 \\
Dried salt-cured shrimp & São Luis, MA & 70 \\
Mangrove crab (Ucides cordatus) & S. Caetano de & 59 \\
& Odivels, PA & \\
Weakfish (Cynoscion leiarchus) & Florianópolis, SC & 11 \\
Blue crab (Callinectes sapidus) & Florianópolis, SC & 11 \\
Sushi & Fortaleza, CE & 1 \\
\hline
\end{tabular}


Table 7

Isolation of Listeria from seafood in Brazil (product, location, reference)

\begin{tabular}{lcc}
\hline Product & Location & Reference \\
\hline $\begin{array}{l}\text { Fresh shrimp (Penaeus } \\
\text { brasiliensis) }\end{array}$ & São Paulo, SP & 22,94 \\
$\begin{array}{l}\text { Frozen shrimp (P. subtilis, } \\
\text { Xiphopenaeus kroyeri) }\end{array}$ & Rio de Janeiro, RJ & 41 \\
$\begin{array}{l}\text { Fresh/frozen shrimp (exported) } \\
\text { Smoked surubim }\end{array}$ & USA & 33 \\
(Pseudoplatystoma sp.) & São Paulo, SP & 7,101 \\
Smoked salmon & São Paulo, SP & 18 \\
\hline
\end{tabular}

RJ = Rio de Janeiro; SP = São Paulo. Source: Destro (2000) (modified).

safety depends primarily on environmental conditions, and not even the best efforts at bacteriological control during handling, processing and distribution can completely eliminate, or reduce to acceptable levels, the risks to which consumers might be exposed ${ }^{48,120}$. This is reflected by the significant incidence of seafood-related gastroenteritis caused by Vibrio parahaemolyticus in countries as different as Brazil, Chile ${ }^{36}$ and the USA ${ }^{50}$.

The traditional methods of prevention and control of bacteriological contamination are gradually being replaced by an approach referred to as "Hazard Analysis and Critical Control Point" (HACCP) which identifies and attempts to eliminate all possible hazards at each step of the food production and distribution process. To be effective, HACCP requires the adoption of a range of sanitary procedures, such as the Good Manufacturing Practices (GMP) derived from the General Principles of Food Hygiene of the Codex Alimentarius (CODEX) ${ }^{13,45,48}$. In addition to HACCP, the CODEX Commission and the World Trade Organization (WTO) recommend the adoption of another approach - food safety risk analysis - to ensure safety and protect public health.

HACCP-based prevention and control systems are increasingly popular worldwide. The fishing industry was the first food sector to implement HACCP and remains one of its most important users. Food safety risk analysis, on the other hand, is still at an early stage, especially in developing countries.

HACCP is science-based and identifies specific hazards and control measures in order to ensure food safety. Rather than sampling and analyzing final products, HACCP focuses on how to prevent and eliminate hazards, provided a number of prerequisites are met. HACCP is accepted and recommended worldwide and has become part of food legislation in most countries ${ }^{13}$.

Food safety risk analysis is a systematic approach to the potential risks represented by foods. It includes three procedures: management, assessment and communication of risks. With this approach, it can usually be determined objectively whether a specific food attribute represents a health risk and how serious the risk is to public health. The definitions given to the terms "hazard" and "risk" are essential to understanding how the instrument works. According to CODEX, a hazard is a biological, chemical or physical agent in, or condition of, food with the potential to cause an adverse health effect, while risk is a function of the probability of an adverse effect and the magnitude of that effect, consequential to a hazard in food ${ }^{103}$.
To correctly apply HACCP and food safety risk analysis to the prevention and control of Food-borne illnesses caused by pathogenic bacteria associated with the consumption of seafood, extensive knowledge is required regarding the survival and growth of these microorganisms in the environment, in seafood and in infected humans, along with the epidemiology and symptomatology of the diseases with which they are associated ${ }^{30}$. Such knowledge is indispensable for the identification of the hazards and risks associated with the presence of pathogenic bacteria in seafood and for the development effective strategies for their prevention and control.

\section{CONCLUSIONS}

The revision identified main bacterial hazards and risks to seafood consumers in Brazil, as well as outbreaks, cases, deaths and types of seafood associated with these hazards and risks. Collected information indicates that the occurrence of seafood-borne bacterial illnesses in Brazil chiefly depends of food diet and food preparation habits, confirming the common knowledge that when seafood is adequately cooked it does not offer risk to human health. Safety hazards and risks are linked to the internationally spread habit of raw fish consumption of popular seafood dishes such as sushi, sashimi, ceviche, carpaccio. The particular association of between consumption of mollusk bivalves and bacterial seafood-borne illnesses should be once more emphasized.

The lack of quantitative and qualitative statistical and epidemiological data reflected by the review indicates the need for increasing research efforts in these areas aiming to prevent and control seafood-borne bacterial illnesses in our country.

\section{RESUMO}

\section{Perigos e riscos bacteriológicos associados ao consumo de pescado no Brasil}

Esta revisão apresenta dados qualitativos e quantitativos sobre doenças bacterianas e achados laboratoriais associados ao consumo de pescado e derivados no Brasil de 1983 a 2011. Os resultados mostram uma séria lacuna de dados epidemiológicos relacionados a surtos causados por pescado. Os poucos dados disponíveis indicam que em contraste com outros surtos alimentares transmitidos por carne, aves, laticínios e vegetais, as bactérias patogênicas teriam um menor destaque na transmissão destas doenças pelo consumo de pescado e derivados. Vibrio parahaemolyticus parece ser a causa mais frequente das doenças causadas pelo consumo de pescado e derivados, bem como a bactéria patogênica mais comumente presente nesses produtos nas investigações laboratoriais.

\section{REFERENCES}

1. Albuquerque WF, Evangelista-Barreto NS, Silva AIM, Vieira RHSF. Ocorrência de Vibrio parahaemolyticus e estafilococos coagulase positivo, em sushis comercializados em alguns estabelecimentos de Fortaleza-CE. Hig Aliment. 2006;20:58-61.

2. Almeida $\mathrm{F}^{\circ}$ ES, Sigarini CO, Lindner AL, Sales KG, Stelatto E, Ribeiro JN et al. Avaliação microbiana de "pintado" (Pseudoplatystoma fasciatum) proveniente da região do Pantanal Matogrossense e comercializado na cidade de Cuiabá, Brasil. Hig Aliment. 2003;17(104-105):81-4. 
3. Almeida $\mathrm{F}^{\mathrm{o}} \mathrm{ES}$, Sigarini CO; Valente AM, Oliveira LAT, Franco RM, Carvalho JCP. Perfil bacteriológico do bacalhau (Gadus morrhua) salgado seco comercializado no Município de Niterói, RJ. Hig Aliment.. 2003;17(104-105):66-7.

4. Almeida $\mathrm{F}^{\circ}$ ES, Valente AM, Stussi JSP, Oliveira LAT, Franco RM, Carvalho JCAP Vibrio vulnificus em pescado, uma revisão. Hig Aliment. 2004;18(116-117):23-8.

5. Alvares PP, Martins L, Borghoff T, Silva WA, Abreu TQ, Gonçalves FB. Análise das características higiênico-sanitárias e microbiológicas de pescado comercializado na Grande São Paulo. Hig Aliment. 2008(161);22:88-93.

6. Alves LMC, Costa NF, Silva MS, Sales SS, Correia MR. Toxinfecção alimentar por Salmonella enterentides: relato de um surto ocorrido em São Luís-MA. Hig Aliment. 2001;15(80-81):57-8

7. Alves VF, Martinis EC, Destro MT, Vogel BF, Gram L. Antilisterial activity of a Carnobacterium piscicola isolated from Brazilian smoked fish (surubim [Pseudoplatystoma sp.]) and its activity against a persistent strain of Listeria monocytogenes isolated from surubim. J Food Prot. 2005;68:2068-77.

8. Amagliani G, Brandi G, Schiavano GF. Incidence and role of Salmonella in seafood safety. Food Res Int. 2012;45:780-8.

9. ANVISA. Agência Nacional de Vigilância Sanitária. Regulamento técnico sobre os padrões microbiológicos para alimentos. Resolução $\mathrm{N}^{\circ} 12$, de 2 de janeiro de 2001. Diário Oficial da República Federativa do Brasil, Brasília, DF, 10 jan. 2001. [cited 2009 Mar 06]. Available from: http://www.anvisa.gov.br/legis/resol/12_01rdc.htm>

10. Archer RM, Moretto E. Ocorrência de Vibrio parahaemolyticus em mexilhões (Perna perna, Limnaeus, 1758) de banco natural do litoral do município de Palhoça, Santa Catarina. Cad Saúde Pública. 1994;10:379-86.

11. Ayulo AM, Machado RA, Scussel, VM. Enterotoxigenic Escherichia coli and Staphylococcus aureus in fish and seafood from the Southern region of Brazil. Int J Food Microbiol. 1994;24:171-8

12. Barreto TL, Sturion, GL. Perfil epidemiológico dos surtos de toxinfecções alimentares em um município do Estado de São Paulo. Hig Aliment. 2010;24(180/181):78-84.

13. CAC. The Codex Alimentarius Commission. Hazard Analysis and Critical Control Point (HACCP) System and Guidelines for its application. In: "Recommended International Code of Practice. General Principles of Food Hygiene". (CAC), CAC/RCP 1-1969, Rev. 4(2003), Rome: FAO; 2003. p. 21-31

14. Carvalho FCT. Influência exógena na qualidade bacteriológica da água, solo e camarão (Litopenaeus vannamei), em quatro fazendas de camarão do Estado do Ceará [Dissertação]. Fortaleza: Universidade Federal do Ceará, Instituto de Ciências do Mar; 2006.

15. CDC. Centers for Disease Control and Prevention. Fact sheets. Salmonella, July 1999 Office of communication media relations. CDC; 1999. [cited 2011 Jul 06]. Available from: <http://www.cdc.gov/od/oc/media/fact/salmonella.htm>

16. Costa RA, Vieira GHF, Silva GC, Vieira RHSF, Sampaio SS. Susceptibilidade in vitro a antimicrobianos de estirpes de Vibrio spp. isoladas de camarões (Litopenaeus vannamei) e de água de criação destes animais provenientes de uma fazenda de camarões no Ceará - nota prévia. Braz J Vet Res Animal Sci. 2008;45:458-62.

17. Costa Sobrinho P, Destro MT, Franco BDGM, Landgraf M. Occurrence and distribution of Vibrio parahaemolyticus in retail oysters in São Paulo State, Brazil. Food Microbiol. 2011;28:137-40

18. Cruz CD, Silvestre FA, Kinoshita EM, Landgraf M, Franco BDG, Destro MT. Epidemiological survey of Listeria monocytogenes in a gravlax salmon processing line. Braz J Microbiol. 2008;39:375-83

19. CVE. Centro de Vigilância Epidemiológica. Centro de Controle de Doenças, Secretaria de Estado da Saúde de São Paulo (SES). Divisão de Doenças de Transmissão Hídrica e Alimentar (DDTHA). Botulismo - Casos confirmados notificados ao CVE, ESP, 1997 a 2008. Tabela Excel. 2009. [cited 2011 Aug 11]. Available at: <http://www. cve.saude.sp.gov.br/htm/hidrica/dados/Botu_sh9708.xls>.
20. Dalsgaard A, Alarcon A, Lanata CF, Jensen T, Hansen HJ, Delgado F, et al. Clinica manifestations and molecular epidemiology of five cases of diarrhoea in children associated with Vibrio metschnikovii in Arequipa, Peru. J Med Microbiol 1996:45:494-500.

21. Desmarchelier PM. Pathogenic Vibrios. In: Hocking AD, Arnold G, Jenson L, Newton K, Sutherland P, editors. Foodborne microorganisms of public health significance. $5^{\text {th }}$ ed. North Sydney: Australian Institute of Food Science and Technology; 1997. p. 285-312.

22. Destro MT, Piva FC, Leitão MFF, Landgraf M. Occurrence of Listeria spp. in shrimp (Penaeus brasiliensis) from a Brazilian processing plant. In: Proceedings of the $3^{\text {r }}$ International ASEPT Conference, Food Safety 94. Laval, France, 1-2 June 1994 p. 330 .

23. Destro MT. Incidence and significance of Listeria in fish and fish products from Latin America. Int J Food Microbiol. 2000;62:191-6.

24. DSMZ. Deutsche Sammlung von Mikroorganismen und Zellkulturen GmbH. 2011 [cited $2011 \mathrm{Jul}$ 06]. Available from: <http://www.dsmz.de/bactnom/bactname.htm>

25. Eduardo MBP, Melo MLR, Katsuya EM, Moraes IR, Pascuet N, Badolato ES, et al. Manual das doenças transmitidas por alimentos e água: Clostridium botulinum/ Botulismo. São Paulo: Secretaria de Saúde do Estado de São Paulo; 2002.

26. Eduardo MBP, Sikusawa S. O botulismo no Brasil e o trabalho desenvolvido pelo Centro de Referência do Botulismo. Hig Aliment. 2003;17(104/105):60.

27. Elliot EL, Kaysner CA, Jackson L, Tamplin ML. Vibrio cholerae, V. parahaemolyticus, V. vulnificus and other Vibrio spp. In: FDA bacteriological analytical manual. $8^{\text {th }}$ ed. Gaithersburg: AOAC International; 1995. p. 9.01- 9.27.

28. FAO. Sistemas nacionales de inocuidad de alimentos en las Américas y El Caribe: análisis de la situación. In: Conferencia regional FAO/OMS sobre inocuidad de lo alimentos para las Américas y El Caribe. San José, Costa Rica, 6-9 de diciembre de 2005. Documento 05/2. Santiago: FAO; 2005.

29. Farber JM, Peterkin PI. Listeria monocytogenes: a food borne pathogen. Microbiol Rev 1991;55:476-511.

30. Figueiredo AVA, Miranda MS. Análise de risco aplicada aos alimentos no Brasil: perspectivas e desafios. Ciên Saúde Colet. 2011;16:2251-62

31. Frazier WC, Westhoff DC. Food Microbiology. $4^{\text {th }}$ ed. New York: Mc Graw-Hill; 1988

32. FUNASA. Investigação do surto de gastroenterite por Vibrio parahaemolyticus em Fortaleza/CE, setembro de 2002. Fundação Nacional de Saúde (FUNASA), Ministério da Saúde. Bol Eletrônico Epidemiol. 2002;2(4):5-7.

33. Gecan JS, Bandlert R, Staruszkiewicz WF. Fresh and frozen shrimp: a profile of filth, microbiological contamination and decomposition. J Food Prot. 1994;57:154-8.

34. Gelli DS, Jakabi M, Souza A. Botulism: a laboratory investigation on biological and food samples from cases and outbreaks in Brazil (1982-2001). Rev Inst Med Trop Sao Paulo. 2002;44:321-4.

35. Gelli DS, Tachibana T, Sakuma H. Ocorrência de V. parahaemolyticus, Escherichia coli e de bactérias mesófilas em ostras. Rev Inst Adolfo Lutz. 1979;39:61-6.

36. Harth E, Matsuda L, Hernandez C, Rioseco ML, Romero J, González-Escalona N, et al Epidemiology of Vibrio parahaemolyticus outbreaks, southern Chile. Emerg Infect Dis. $2009 ; 15: 163-8$

37. Hatha AAM, Maqboolb TK, Suresh Kumarb S. Microbial quality of shrimp products of export trade produced from aquacultured shrimp. Int J Food Microbiol. 2003;82:213-

38. Hofer E. Primeiro isolamento e identificação de Vibrio parahaemolyticus no Brasil de infecção gastrointestinal humana. Rev Microbiol. 1983;14:174-82. 
39. Hofer E. Vibrio cholerae não-O1 associado à infecção humana no Estado da Bahia. Rev Microbiol. 1987;18:1-4

40. Hofer E, Reis, EMF. Salmonella serovars in food poisoning episodes recorded in Brazil from 1982 to 1991. Rev Inst Med Trop Sao Paulo. 1994;36:7-9.

41. Hofer E, Ribeiro R. Ocorrência de espécies Listeria em camarão industrializado. Rev Microbiol. 1990;21:207-8

42. Hofer E, Silva CHD. Isolamento e identificação de Vibrio parahaemolyticus de material de peixes de origem marinha. In: V Congresso Brasileiro de Microbiologia. Anais. Rio de Janeiro: Universidade Gama Filho; 1974

43. Horré R, Marklein G, Schaal KP. Vibrio vulnificus and emerging human pathogen. Zentralbl Bakteriol. 1996;284:273-84.

44. Huq A, Small BE, West AP, Huq MI, Rahman RR, Colwell, RR. Ecological relationships between Vibrio cholerae and planktonic crustacean copepods. Appl Environ Microbiol. 1983;45:275-83.

45. Huss HH. Development and use of the HACCP concept in fish processing. Int J Food Microbiol. 1992;15:33-44.

46. Huss HH. Control of indigenous pathogenic bacteria in seafood. Food Control. 1997;8:91-8.

47. Huss HH, Ababouch L, Gram L. Assessment and management of seafood safety and quality. Rome: FAO; 2003. FAO Fish Tech Paper. (444).

48. Huss HH, Reilly A, Ben Embarek PK. Prevention and control of hazards in seafood. Food Control. 2000;11:149-56.

49. ICMSF. International Commission on Microbial Specifications for Foods. Microorganisms in foods. Part III: specifications for ingredients, media, and reagents, $2^{\text {nd }}$ ed. Toronto: University of Toronto Press; 1978.

50. Iwamoto M, Ayers T, Mahon BE, Swerdlow DL. Epidemiology of seafood-associated infections in the United States. Clin Microbiol Rev. 2010;23:399-411.

51. Kaper JB, Morris JG Jr, Levine MM. Cholera. Clin Microbiol Rev. 1995;8:48-86.

52. Ketcham EM, Gomez HF. Infant botulism: a diagnostic and management challenge. Air Med J. 2003;22:6-11.

53. Kumar HS, Sunil R, Venugopal MN, Karunasagar I, Karunasagar I. Detection of Salmonella spp. in tropical seafood by polymerase chain reaction. Int J Food Microbiol. 2003;88:91-5.

54. Lafisca A, Pereira CS, Giacone V, Rodrigues DP. Enzymatic characterization of Vibrio alginolyticus strains isolated from bivalves harvested at Venice Lagoon (Italy) and Guanabara Bay (Brazil). Rev Inst Med Trop Sao Paulo. 2008;50:199-202.

55. Larsen HS, Mahon CR. Staphylococcus. In: Mahon CR, Manuselis Jr. G, editors. Diagnostic microbiology. Philadelphia: W.B. Saunders; 1995. p. 325-38.

56. Leitão MFF, Kai M, Arima HK. Vibrio parahaemolyticus no ambiente marinho do Estado de São Paulo: incidência em peixes, moluscos e crustáceos. Col Inst Tecnol Aliment (Campinas). 1976;7:181-90.

57. Linder CE, Roça RO, Pinto JPAN, Sigarini CO. Salmonella spp em sistema intensivo de criação de peixes tropicais de água doce. Hig Aliment. 2011;25(192/193):126-33.

58. Lira AA, Barros GC, Mota RA. Vibrio parahaemolyticus em bivalves comercializados no Grande Recife, PE. Hig Aliment. 2001;15(90/91):50-9.

59. Lourenço LFH, Oliveira ML, Pinto CMP, Pereira DXP. Análises físico-químicas e microbiológicas de carne de caranguejo-uçá Ucides cordatus (Linnaeus, 1763), comercializada nos municípios de São Caetano de Odivelas e Belém, PA. Hig Aliment. 2006;20:90-5.
60. Magalhães M, Magalhães V, Antas MG, Tateno S. Caracterização bacteriológica e sorológica de linhagens de Vibrio parahaemolyticus isoladas de humanos e ostras em Recife, PE, Brasil. Rev Microbiol. 1991;22:83-8.

61. Magalhães M, Silva GP, Magalhães V, Antas MG, Andrade MA, Tateno EC. Vibrio fluvialis and Vibrio fumissii associated with infantile diarrhea. Rev Microbiol. 1990;24:295-8.

62. Magalhães V, Lima RA, Tateno S, Magalhães M. Grastroenteritis humanas associadas a Vibrio parahaemolyticus no Recife, Brasil. Rev Inst Med Trop Sao Paulo. 1991:33:648

63. Matté GR, Matté MH, Rivera IG, Martins MT. Distribution of potentially pathogenic vibrios in oysters from a tropical region. J Food Protect. 1994;57:870-3.

64. Matté MH, Baldassi L, Barbosa ML, Malucelli MIC, Nitrini SMOO, Matté GR. Virulence factors of Vibrio metschnikovii strains isolated from fish in Brazil. Food Control. 2007; 18:747-51.

65. Melo LMR, Almeida D, Hofer E, Reis CMF, Theophilo GND, Santos AFM et al. Antibiotic resistance of Vibrio parahaemolyticus isolated from pond-reared Litopenaeus vannamei marketed in Natal, Brazil. Braz J Microbiol. 2011;42:1463-9.

66. Mendes ES, Goes LMNB, Mendes PP, Barros GC, Silva AVL, Souza JCR, et al. Perfil microbiológico da carne de aratú (Goniopsis cruentata) comercializada na região de Recife, PE. Hig Aliment. 2004;17:114-5.

67. Mendes ES, Mendes PP, Lopez CAM, Coelho MIS, Souza JCR, Cruz MCS, et al. Sazonalidade dos microorganismos em ostras consumidas na Grande Recife, PE. Hig Aliment. 2004;18(116):79-87.

68. Muratori MCS. Pesquisa de Salmonella sp. em tilápias consorciadas com suínos e nas águas utilizadas no sistema de criação. Consórcio suíno e peixe: risco ambiental e sanitário. Proposta alternativa para descontaminação. [tese]. Belo Horizonte: Escola de Veterinária/Universidade Federal de Minas Gerais; 2000.

69. Nascimento SM, Vieira RH, Theophilo GN, Rodrigues DP, Vieira GH. Vibrio vulnificus as a health hazard for shrimp consumers. Rev Inst Med Trop Sao Paulo. 2001;43:263-6.

70. Nascimento AR, Mouchrek Filho JE, Taty SR. Pesquisa de coliformes e Staphylococcus enteropatogênicos em camarões salgados secos comercializados nos mercados e feiras-livres de São Luís, MA. Hig Aliment. 2001;15(85):65-8.

71. Nishibuchi M. Vibrio parahaemolyticus. In: Miliotis MD, Bier JW. editors. International handbook of foodborne pathogens. New York: Marcel Dekker; 2003. p. 237-52.

72. Nishibuchi M, Depaola A. Vibrio species. In: Fratamico PM, Bhunia AK, Smith JL, editors. Foodborne pathogens: microbiology and molecular biology. Norfolk: Caister Academic Press; 2005. p. 251-71.

73. Nishibuchi M, Kaper JB. Thermostable direct hemolysin gene of Vibrio parahaemolyticus: a virulence gene acquired by a marine bacterium. Infect Immun. 1995;63:2093-9.

74. Okuda J, Nishibuchi M. Manifestation of the Kanagawa phenomenon, the virulenceassociated phenotype, of Vibrio parahaemolyticus depends on a particular single base change in the promoter of the thermostable direct haemolysin gene. Mol Microbiol. 1998;30:499-511.

75. Oliver JD, Kaper JB. Vibrio species. In: Doyle MP, Beuchat LR, Montville TJ, editors Food microbiology: fundamentals and frontiers. $3^{\text {rd }}$ ed. Washington: ASM Press; 2007. p. 343-79.

76. Pacheco TA, Leite RGM, Almeida AC, Silva NMO, Fiorini JE. Análise de coliformes e bactérias mesofílicas em pescado de água doce. Hig Aliment. 2004;18:68-72.

77. Parente LS, Costa RA, Vieira GHF, Reis EMF, Hofer E, Fonteles AA, et al. Bactérias entéricas presentes em amostras de água e camarão marinho Litopenaeus vanname oriundos de fazendas de cultivo no Estado do Ceará, Brasil. Braz J Vet Res Anim Sci. 2011;48:46-53. 
78. Pereira CS, Possas CA, Viana CM, Rodrigues DP. Vibrio spp. isolados a partir de mexilhões (Perna perna) in natura e pré-cozidos da Estação Experimental de Cultivo, Rio de Janeiro, RJ, Brazil. Ci Tecnol Aliment (Campinas). 2007;27:387-90.

79. Pereira CS, Rodrigues DP, Viana CM. Isolamento de Vibrio spp em mexilhões (Perna perna) coletados na região de Ponta de Itaipú, Niterói, RJ. Hig Aliment. 2007;21:94-7.

80. Pereira CS, Viana CM, Rodrigues DP. Vibrio parahaemolyticus produtores de urease isolados a partir de ostras (Crassostrea rhizophorae) coletadas in natura em restaurantes e mexilhões (Perna perna) de banco natural. Ci Tecnol Aliment (Campinas). 2004;24:591-5

81. Pereira CS, Viana CM, Rodrigues DP. Víbrios patogênicos em ostras (Crassostrea rhizophorae) servidas em restaurantes no Rio de Janeiro: um alerta para a saúde pública. Rev Soc Bras Med Trop. 2007;40:300-3.

82. Pereira MA, Nunes MM, Nurenberg L, Schultz D, Batista CRV. Microbiological quality of oysters (Crassostrea gigas) produced and commercialized in the coastal region of Florianópolis, Brazil. Braz J Microbiol. 2006,37:159-63.

83. Pereira CS, Possas CA, Viana CM, Rodrigues DP. Características de Vibrio parahaemolyticus isolados de mexilhões (Perna perna) comercializados em Niterói, Rio de Janeiro. Rev Soc Bras Med Trop. 2007;40:56-9.

84. Pinto PSA. Aspectos sanitários da salmonelose como uma zoonose. Hig Aliment. 2000;14(71):39-43

85. Pires SM, Vieira AR, Perez E, Lo Fo Wong D, Hald T. Attributing human foodborne illness to food sources and water in Latin America and the Caribbean using data from outbreak investigations. Int J Food Microbiol. 2012;152:129-38.

86. Rall VLM, Cardoso KFG, Xavier C. Qualidade microbiológica de pescado comercializado na cidade de Botucatu, SP. Hig Aliment. 2011;25(192/193):123-5.

87. Ristori CA, Iaria ST, Gelli DS, Rivera IN. Pathogenic bacteria associated with oysters (Crassostrea brasiliana) and estuarine water along the south coast of Brazil. Int J Environ Health Res. 2007;17:259-69.

88. Rodrigues DP, Hofer E. Vibrio species from the water-oyster ecosystem of Sepetitiba Bay in Rio de Janeiro State, Brazil. Rev Microbiol. 1986;17:332-8.

89. Rodrigues RD, Queiroz AMP, Bergmann GP, Cardoso S. Avaliação de postas de corvina (Micropogon furnieri) comercializadas no mercado público de Porto Alegre, RS. Hig Aliment. 2003;17:165-6.

90. Rodrigues RL, Leite MO, Franco RM, Oliveira LAT. Avaliação bacteriológica de carne de rã (Leptodactylus sp.) congelada comercializada em Niterói, RJ. Hig Aliment. 1994;8:19-24.

91. Rojas MVR, Matté MH, Dropa M, Silva ML, Matté GR. Characterization of Vibrio parahaemollyticus isolated from oysters and mussels in São Paulo, Brazil. Rev Inst Med Trop Sao Paulo. 2011;53:201-5.

92. Santiago O. Toxi-infecções produzidas por alimentos. Brasília: Departamento Naciona de Inspeção de Produtos de Origem Animal, DIPOA, Ministério da Agricultura; 1972.

93. Santos CAML. Doenças transmitidas por pescado no Brasil. Rev Bras Med Vet 2010;32:234-41

94. Santos CAML. Doenças transmitidas por pescado no Brasil: análise preliminar dos dados disponíveis. In: IV Simpósio de Controle do Pescado (SIMCOPE) e XVI Reunião da Rede Panamericana de Inspeção, Controle de Qualidade e Tecnologia de Pescado (REDPAN), Santos-SP, Brasil, 20-24 set 2010.

95. Scarcelli E, Piatti RM. Patógenos emergentes relacionados à contaminação de alimentos de origem animal. O Biológico (Sao Paulo). 2002;64:123-7.

96. Serra CLM, Cavalcante PR, Coelho LMA, Nascimento AR, Coutinho MFO. Ocorrência de Vibrio parahaemolyticus em sarnambi (Anomalocardia brasiliana) e sururu (Mytella falcata) capturados no estuário do Rio Anil, São Luís, MA. Hig Aliment. 2004;18(116/117):73-8
97. Silva AIM, Vieira RHSF, Menezes FGR, Fonteles Filho AA, Torres RCO, Sant'ann ES. Bacteria of fecal origin in mangrove oysters (Crassostrea rhizophorae) in the Cocó river estuary, Ceará State, Brazil. Braz J Microbiol. 2003;34:126-30

98. Silva ML, Matté GR, Matté MH. Aspectos sanitários da comercialização de pescado em feiras livres da cidade de São Paulo. Rev Inst Adolfo Lutz. 2008:67:208-14.

99. Sobel J. Botulism. Clin Infect Dis. 2005;41:1167-73.

100. Sousa OV, Vieira RHSF, Menezes FGR, Reis CMF, Hofer E. Detection of Vibrio parahaemolyticus and Vibrio cholerae in oyster, Crassostrea rhizophorae, collected from a natural nursery in the Coco river estuary, Fortaleza, Ceará, Brazil. Rev Inst Med Trop Sao Paulo. 2004;46:59-62.

101. Souza VM, Alves VF, Destro MT, De Martinis ECP. Quantitative evaluation of Listeria monocytogenes in fresh and processed surubim fish (Pseudoplatystoma $\mathrm{sp}$ ). Braz J Microbiol. 2008:39:527-8.

102. Su YC, Liu C. Vibrio parahaemolyticus: a concern of seafood safety. Food Microbiol 2007;24:549-58

103. Sumner J, Ross T, Ababouch L. Application of risk assessment in the fish industry. Rome: FAO; 2004. FAO Fish Tech Paper. (442).

104. SVS. Secretaria de Vigilância em Saúde. Análise epidemiológica dos surtos de doenças transmitidas por alimentos no Brasil. Brasília: Ministério da Saúde; 2009. (Apresentação Power Point: 15 slides)

105. Theophilo GN, Vieira RH, Rodrigues DP, Menezes FG. Escherichia coli isolated from seafood: toxicity and plasmid profiles. Int Microbiol. 2002;5:11-4.

106. Trabulsi LR, Alterthum F. Microbiologia. $5^{\mathrm{a}}$ ed. São Paulo: Atheneu, 2008. 780p.

107. Vieira KVM, Maia DCC, Janebro DI, Vieira RHSF, Ceballos BSO. Influência das condições higiênico-sanitárias no processo de beneficiamento de tilápias (Oreochromis niloticus) em filés congelados. Hig Aliment. 2000;14:37-40.

108. Vieira RHSF. Microbiologia, higiene e qualidade do pescado: teoria e prática. S. Paulo: Livraria Varela; 2004

109. Vieira RHSF, Atayde MA, Carvalho EMR, Carvalho FCT, Fonteles $F^{\circ}$ AA. Contaminação fecal da ostra Crassostrea rhizophorae e da água de cultivo do estuário do Rio Pacoti (Eusébio, Estado do Ceará): isolamento e identificação de Escherichia coli e sua susceptibilidade a diferentes antimicrobianos. Braz J Vet Res Anim Sci. 2008;45:180-9.

110. Vieira RHSF, Cavalcante DSP, Saker-Sampaio SS. Algumas espécies do gênero Vibrio em lagostas e camarões. Arq Ci Mar. 1987;26:1-5.

111. Vieira RHSF, Costa, RA, Menezes FGR, Silva GC, Teophilo GND, Rodrigues DP, et al. Kanagawa-negative, tdh- and trh-positive Vibrio parahaemolyticus isolated from fresh oysters marketed in Fortaleza, Brazil. Curr Microbiol. 2011;63:126-30.

112. Vieira RHSF, Iaria ST. Detecção de Vibrio parahaemolyticus em cauda de lagosta (Panulirus laevicauda, Latreille). Rev Microbiol. 1993;24:16-21.

113. Vieira RHSF, Lima EA, Sousa DBR, Reis EMF, Costa RG, Rodrigues DP. Vibrio spp and Salmonella spp. presence and susceptibility in crabs Ucides cordatus. Rev Inst Med Trop Sao Paulo. 2004;46:179-82.

114. Vieira RHSF, Sousa OV, Costa RA, Theophilo GND, Macrae A, Fonteles Filho AA, et al. Raw oysters can be a risk for infections. Braz J Infect Dis. 2010;14:66-70.

115. Wachsmuth K. Molecular epidemiology of cholera. In: Wachsmuth IK, Blake PA, Olsvik B, editors. Vibrio cholerae and cholera: molecular to global perspectives. Washington American Society for Microbiology Press; 1994

116. WHO. Cholera response: assessing the outbreak response and improving preparedness Geneve: Global Task Force on Cholera Control, WHO; 1994. 
117. WHO/FAO. Risk assessment of Vibrio vulnificus in raw oysters: interpretative summary and technical report. Rome: FAO; 2005. Microbiological Risk Assessment Series No. 8 .

118. WHO/FAO. Risk assessment of Vibrio parahaemolyticus in seafood. Rome: FAO; 2011. Microbiological Risk Assessment Series No. 16

119. Wong HC, Chen MC, Liu SH, Liu DP. Incidence of highly genetically diversified Vibrio parahaemolyticus in seafood imported from Asian countries. Int J Food Microbiol. 1999;52:181-8
120. Yasuda T, Bowe RE. Chain of custody as an organizing framework in seafood risk reduction. Mar Pollut Bull. 2006;53:640-9.

Received: 17 October 2012

Accepted: 6 December 2012 